\title{
ISOLATION AND PURIFICATION OF RECOMBINANT OUTER SURFACE PROTEIN C (rOspC) OF BORRELIA BURGDORFERI Sensu Lato.
}

\author{
Michal Křupka ${ }^{a *}$, Jana Bělákováa, Martina Šebestováa Jana Tuháčkováb, Milan Raška ${ }^{a}$, \\ Vladimír Vrzal ${ }^{\mathrm{b}}$, Evžen Weigla
}

a Department of Immunology, Faculty of Medicine, Palacký University, Olomouc

b Bioveta, a. S., Ivanovice na Hané

e-mail:majkl.krupka@centrum.cz

Received: September 16, 2005; Accepted (with revisions): November 11, 2005

Key words: OspC/Borrelia burgdorferi/Recombinant protein/Immobilized metal ion affinity chromatography

The aim of this work was isolation and purification of the major immunodominant protein, Outer surface protein $\mathrm{C}(\mathrm{OspC})$ of three members of the species group Borrelia burgdorferi, the causative agent of Lyme disease. Our aim was to obtain this protein in a quantity and purity sufficient for immunization of experimental animals. For optimalization of protein purification's yield we used immobilized metal ion affinity chromatography (IMAC) under different conditions. The greatest efficiency was achieved by using of HiTrap ${ }^{\mathrm{TM}}$ Chelating Column under native conditions.

\section{INTRODUCTION}

The Borrelia burgdorferi species group is a complex of eleven genomic species of spirochetes, of which three are causative agents of Lyme disease, the most common tickborne human disease ${ }^{1}$. Borrelia burgdorferi sensu stricto is the only pathogenic species in USA. Borrelia garinii and Borrelia afzelii are more common in Europe. The reser- voir hosts of this pathogens are mostly rodents, deer and rarely birds. The most important vectors are ticks (Ixodes spp.)( ref. $\left.^{2}\right)$.

OspC is a membrane lipoprotein with a native molecular weight of about $23 \mathrm{kDa}$. The OspC monomer is almost all helical, with four long helices plus one short helix. A biologically active OspC is anchored in the spirochete's outer membrane in the form of dimers ${ }^{3}$. OspC is probably

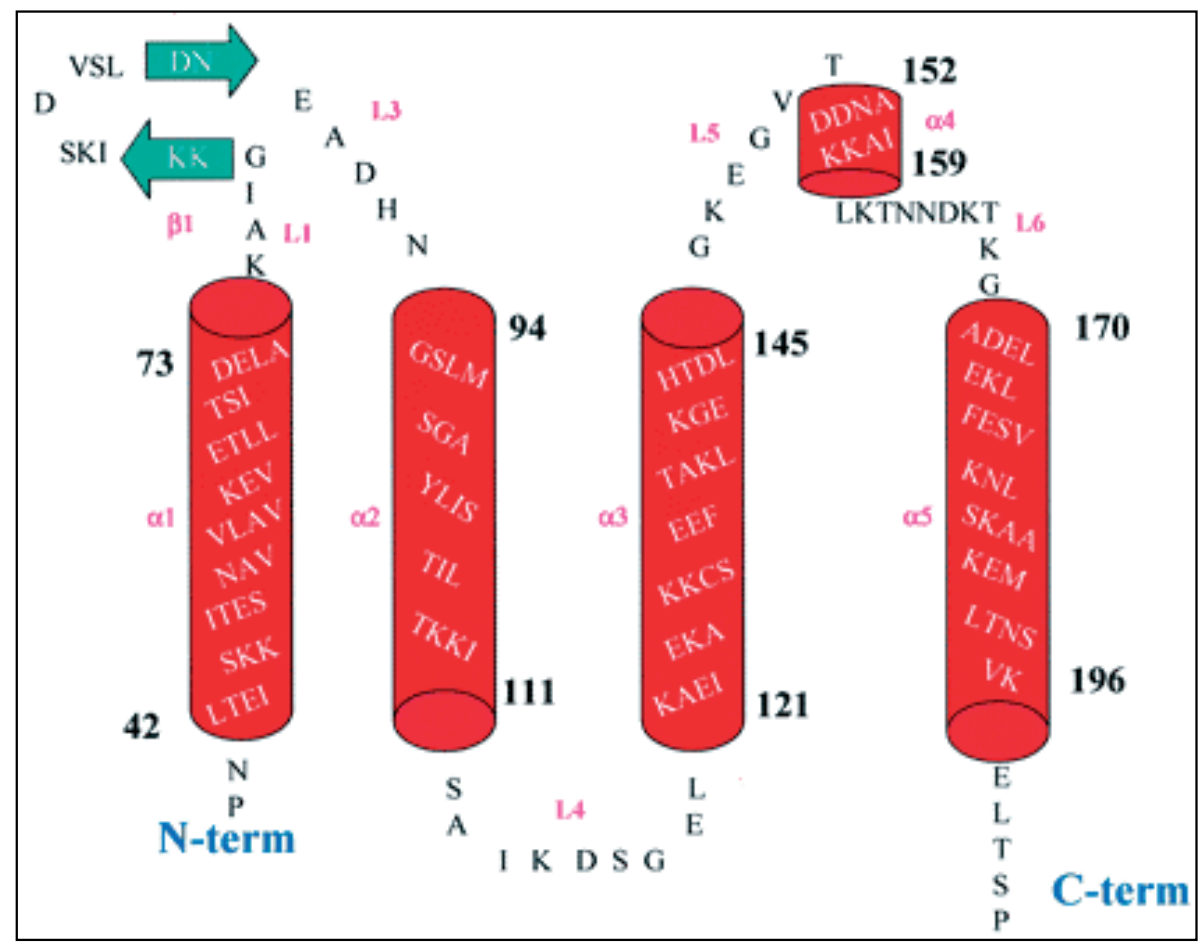

Fig. 1. Structure of Outer surface protein C B. burgdorferi s., from Kumaran et $\mathrm{al}^{3}$. 
important during transmission of spirochetes from ticks to mammals and in the colonization of host tissues ${ }^{4}$. OspC is a good candidate for preparation of vaccine against Lyme disease, due to its strong immunogenity and availability to neutralizing antibodies ${ }^{5}$.

\section{MATERIAL AND METHODS}

The gene sequences coding OspC was amplified from all three species plasmid DNA, and ligated into the expression plasmid pET 28a (Novagen). This construct was then inserted into Escherichia coli, strain BL 21. The used plasmid contains Kanamycin resistance cassete and T7 and 6xHis tags for detection and purification of expressed protein. His-tag is a common purification tag used for immobilized metal affinity chromatography (IMAC) onestep purification ${ }^{6}$.

The cells was cultured in LB medium at $37{ }^{\circ} \mathrm{C}$ to O.D. $=0.6$, then derepressor isopropyl- $\beta$-D-thiogalactopyranoside (IPTG) was added and cultivation continued for another $4 \mathrm{~h}$. The cells were harvested by centrifugation (centrifuge Jouan KR 25i, 10.000 RPM, $4{ }^{\circ} \mathrm{C}, 10 \mathrm{~min}$ ). From 1 liter of culture about 2 grams of bacterial pellet were harvested. The following methods were used in cell lysis and purification.

A) Lysis in phosphate lysis buffer $(5 \mathrm{ml} / \mathrm{g}$ of bacterial pellet) with lysosyme (Sigma, $0,5 \mathrm{mg} / \mathrm{ml}$ of buffer) and sonication with ultrasound sonicator (Hielscher UP200S, $10 \times 10 \mathrm{~s}$, amplitude $70 \%$ ) followed by purification on Ni-NTA agarose (Qiagen, $1 \mathrm{ml} / 4 \mathrm{ml}$ of lysate). Elution was performed with high concentration of imidazole ( $250 \mathrm{mM}$, Fig. 2)

B) Lysis in denaturant buffer containing $8 \mathrm{M}$ urea (Serva, $5 \mathrm{ml} / \mathrm{g}$ of bacterial pellet) and sonication followed by purification on Ni-NTA agarose (Qiagen, $1 \mathrm{ml} / 4 \mathrm{ml}$ of lysate). Elution was performed with decreasing $\mathrm{pH}$ (pH 6.3, 5.9 and 4.5, Fig. 3) Elution fractions were dialyzed against phosphate buffer saline (PBS).

C) Lysis in phosphate lysis buffer with lysozyme and sonication followed by purification on $\mathrm{Ni}$ - Sepharose ${ }^{\mathrm{TM}}$ High Performance (Amersham Biosciences, $1 \mathrm{ml} / 4 \mathrm{ml}$ of lysate). Elution was performed with high concentration of imidazole (250 mM, Fig. 4)

D) Lysis in phosphate lysis buffer with lysozyme and sonication followed by purification on $\mathrm{Ni}^{2+}$ - HiTrap ${ }^{\mathrm{TM}}$ Chelating Column (Amersham Biosciences). Elution was carried out by means of:

I. high concentration of imidazole (250 mM, Fig. 5) or with

II. ethylenediaminetetraacetic acid (EDTA, $50 \mathrm{mM}$ ) after washing with gradient of imidazole (Fig. 6).

Composition of all buffer used was in accordance with QIAexpressionist manual (Qiagen) with addition of protease inhibitors (PMSF, leupeptin, aprotinin) and $\beta$ - mercaptoethanol (Fluka, $5 \mathrm{mM}$ ) in native buffers. Lysis buffer with higher concentration of imidazol $(30 \mathrm{mM})$ was used for washing. Volume of wash fractions was the same as the lysate volume.

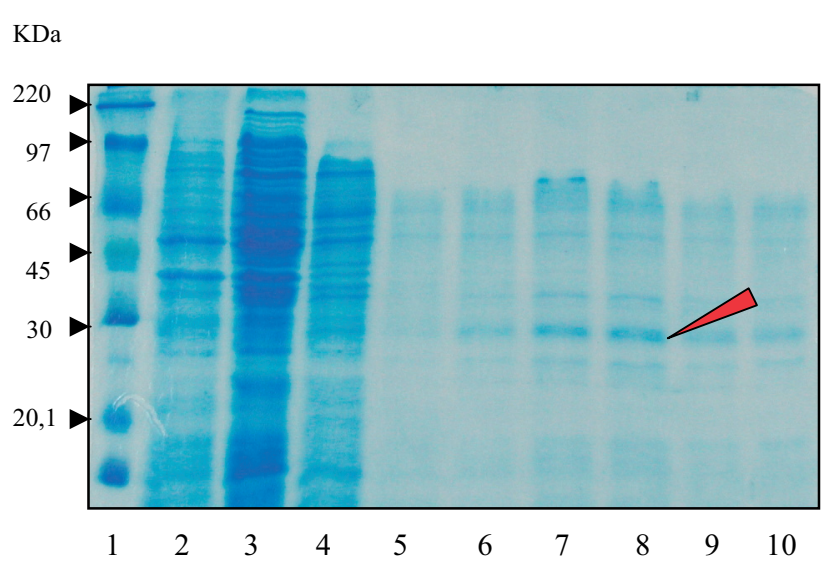

Fig. 2. SDS - PAGE analysis of lysis in phosphate buffer followed by purification on Ni - NTA agarose (method A). lane 1 - standard, lane 2 - lysis pellet, lane 3 - flow through fraction, lane 4 - wash 1 fraction, lane 5 - wash 2 fraction, lane 6-10 - elution fractions.

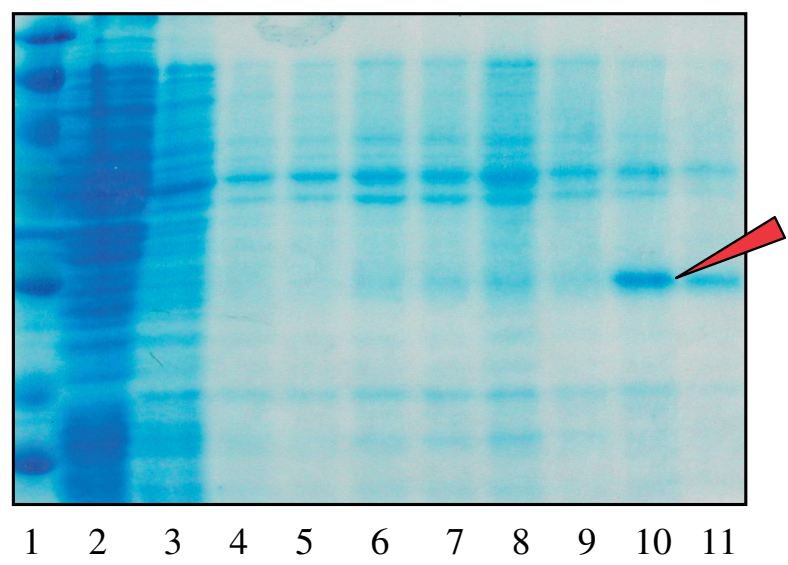

Fig. 3. SDS - PAGE analysis of lysis in denaturant buffer followed by purification on Ni - NTA agarose (method B, standard same as on fig. 2). lane 1 - standard, lane 2 - flow through fraction, 3 - lysis pellet, lane 4-5 - wash fractions with $\mathrm{pH} 6.5$ buffer, lane 6-7 wash fractions with $\mathrm{pH} 5.9$ buffer, lane 8-11 - elution fractions with $\mathrm{pH} 4.5$ buffer.

Separated fractions were analyzed using SDS - PAGE and Western blotting. Electrophoresis gels were stained in Coomasie Blue, membranes with blotted proteins were analyzed with antibody antiT7 HRP conjugate (Novagen, data not shown). All these methods were performed as described in the literature ${ }^{7}$. Protein concentration was measured by densitometric comparition with standard.

The Results of the method used on cells with plasmid containing rOspC B. garinii sequence are shown in Figures 2-6. 


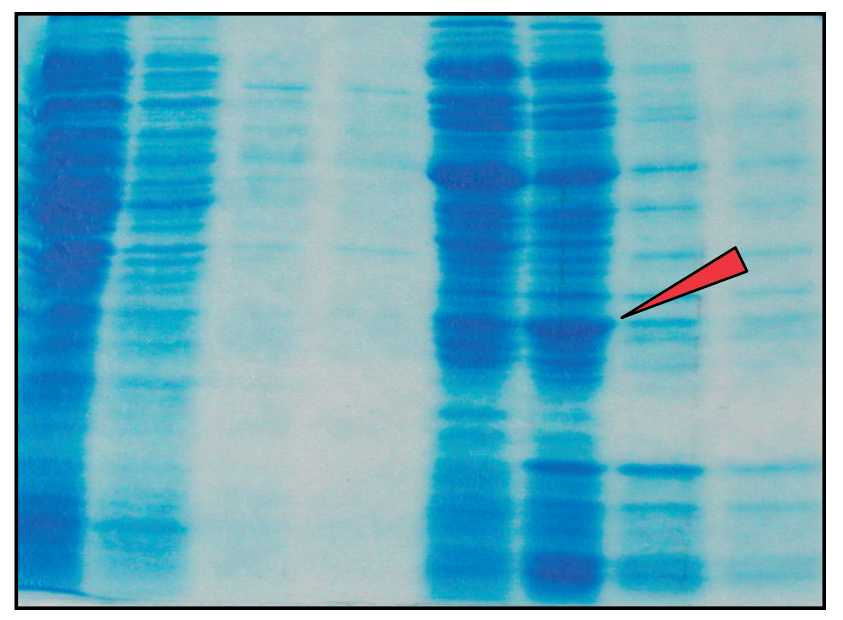

\section{$\begin{array}{llllllll}1 & 2 & 3 & 4 & 5 & 6 & 7 & 8\end{array}$}

Fig. 4. SDS - PAGE analysis of lysis in phosphate buffer followed by purification on $\mathrm{Ni}$ - Sepharose (method C) lane 1 - flow through fraction, lane 2 - wash 1 fraction, lane 3 - wash 2 fraction, lane 4-8 - elution fractions.

\section{RESULTS AND DISCUSSION}

Several methods of cell lysis and IMAC purification of rOspC B. garinii were performed. Using method A, only a low yeast of protein was obtained $(15 \mu \mathrm{l} / \mathrm{ml})$ and the purity was inadequate. We had better results with method B, but it wasn't any forcible tool for verification of the native structure of obtained recombinant protein. Using method $\mathrm{C}$ we obtained a protein of extremly low purity ( $<20 \%$ of total protein) and low concentration. We had the best results with method D. With imidazole elution we obtained protein of sufficient purity and relative high concentration $(400 \mu \mathrm{g} / \mathrm{ml})$. With elution with EDTA, the concentration was somewhat lower (about $200 \mu \mathrm{g} / \mathrm{ml}$ ), but the purity was very high (min. $95 \%$ ). Results with rOspC B. burgdorferi and B. afzelii were very similar (data not shown), so HiTrap ${ }^{\mathrm{TM}}$ Chelating Column was chosen as an optimal tool for purification of rOspC of Borrelia burgdorferi sensu lato.

\section{ACKNOWLEDGEMENT}

We are grateful to Doc. RNDr. J. Kopecký, CSc of the Institute of Parasitology, the Czech Academy of Sciences, České Budějovice and RNDr. J. Turánek, CSc from Veterinary Research Institute, Brno and their co-workers for unselfish help. This work was supported by grant of Ministry of Industry and Business FD -K3/100.
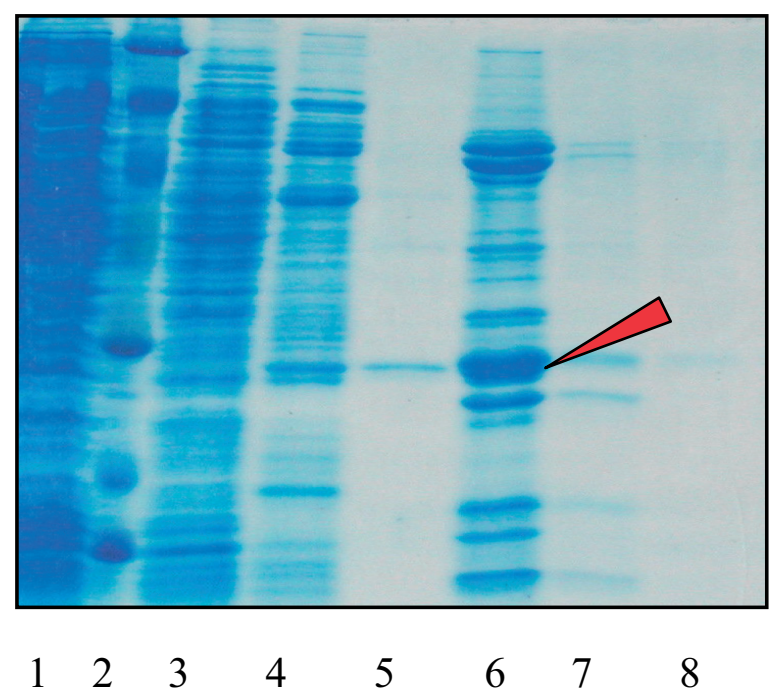

Fig. 5. SDS - PAGE analysis of lysis in phosphate lysis buffer followed by purification on $\mathrm{Ni}^{2+}-\mathrm{HiTrap}^{\mathrm{TM}}$ Chelating Column, elution with imidazole (method D I, standard same as on fig. 2): lane 1 - flow through fraction, lane 2 - standard, lane 3 - wash 1 fraction, lane 4 - wash 2 fraction, lane 5-8 - elution fractions.

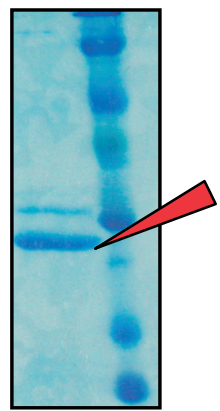

12

Fig. 6. SDS - PAGE analysis of lysis in phosphate lysis buffer followed by purification on $\mathrm{Ni}^{2+}-\mathrm{HiTrap}^{\mathrm{TM}}$ Chelating Column, elution with EDTA (method D II, standard same as on fig. 2): lane 1 - second elution fraction, lane 2 - standard.

\section{REFERENCES}

1. Steere A C, Coburn J \& Glickstein L (2004) The emergence of Lyme disease. J Clin Invest 113, 1093-1101.

2. Dennis D T, Hayes E B. Epidemiology of Lyme Borreliosis. In: Gray JS, Kahl O, Lane RS \& Stanek G., editors. Lyme borreliosis: Biology, Epidemiology and Control. Wallingford: CABI Publishing, 2002. P251-280.

3. Kumaran D, Eswaramoorthy S, Luft BJ, Koide S, Dunn JJ, Lawson CL \& Swaminathan S (2002). Crystal structure of outer surface protein $\mathrm{C}(\mathrm{OspC})$ from the Lyme disease spirochete, Borrelia burgdorferi. The EMBO Journal 20, 971-978 . 
4. Pal U, Yang X, Chen M, Bockenstedt LK., Anderson JF., Flavell RA., Norgard M \& Fikrig E. (2004). OspC facilitates Borrelia burgdorferi invasion of Ixodes scapularis salivary glands. J Clin Invest $113,220-230$

5. Mbow ML, Gilmore RD, Titus RG (1999). An OspC-Specific Monoclonal Antibody Passively Protects Mice from Tick Transmitted Infection by Borrelia burgdorferi B31. Infect Immun 64, 5470-5472.
6. Zouhar J (1999) Chromatography of Proteins on Immobilized Metal Ions. Chem. Listy 93, 683-685. [In Czech]

7. Coligan JE, Dunn BM, Speicher DW \& Wingfield PT (editors). Short protocols in protein science: a compendium of methods from Current protocols in protein science. John Wiley \& Sons, Inc. 2003. 